\title{
Az anaemiák epidemiológiája
}

\author{
Marton Imelda dr. ${ }^{1,2}$ - Agócs Szilvia dr. ${ }^{3}$ - Babik Barna dr. ${ }^{3}$ \\ 'Szegedi Tudományegyetem, Általános Orvostudományi Kar, II. Belgyógyászati Klinika és Kardiológiai Központ, \\ Szeged \\ ${ }^{2}$ Szegedi Tudományegyetem, Általános Orvostudományi Kar, Transzfuziológiai Tanszék, Szeged \\ ${ }^{3}$ Szegedi Tudományegyetem, Általános Orvostudományi Kar, Aneszteziológiai és Intenzív Terápiás Intézet, \\ Szeged
}

\begin{abstract}
Világszerte magas az anaemia prevalenciája, a vashiányos anaemia az ötödik leggyakoribb eltérés a Globális betegségteher címú tanulmány szerint. Hátterében számos tényező, összetett patomechanizmus állhat, az etiológia nagy változatosságot mutat életkor, nem és földrajzi eloszlás szerint. Az anaemia prevalenciája emelkedik az életkorral. A demográfiai változások, a népesség idősödése jelenleg nagyobb léptékü, mint a korábbi évtizedekben, és ez jelentős kihívás elé állítja a társadalmakat és az egészségügyi rendszereket. Az időskori anaemia átlagos prevalenciája 17\%, de ennél lényegesen magasabb az ápolási otthonokban élő (47\%) és a hospitalizációra került idősek (40\%) között. Oka általában multifaktoriális, és gyakran a komorbiditások miatt egyidejúleg több mechanizmus is szerepet játszik a kialakulásában. A preoperatív anaemia prevalenciája magasabb (35\%), mint az anaemia gyakorisága az átlagpopulációban, és evidenciák igazolták kedvezőtlen hatását a posztoperatív morbiditásra és mortalitásra. Időben történő felismerése és korrekciója multidiszciplináris feladat és közös felelősség mind a vértakarékos betegellátás, mind a betegek életkilátásainak javítása szempontjából.
\end{abstract}

Orv Hetil. 2020; 161(37): 1569-1573.

Kulcsszavak: anaemia, hemoglobin, prevalencia, idősödés, mortalitás

\section{Epidemiology of anemia}

Worldwide, the prevalence of anemia is high, and iron deficiency anemia is the fifth most common disorder according to the study called "Global burden of disease". It can be attributed to a number of factors, complex pathomechanisms, and etiology is highly variable in terms of age, gender, and geographical distribution. The prevalence of anemia increases with age. Demographic change and the aging of the population are now faster than in previous decades, posing major challenges to societies and health systems. The mean prevalence of anemia in the elderly is $17 \%$, but significantly higher among nursing-home $(47 \%)$ and hospitalized elderly $(40 \%)$. The cause is usually multifactorial and often, due to comorbidities, several mechanisms are involved at the same time. The prevalence of preoperative anemia was higher $(35 \%)$ than the prevalence of anemia in the general population, and evidence showed an unfavorable effect on postoperative morbidity and mortality. Timely identification and correction is a multidisciplinary task and a shared responsibility for both Patient Blood Management program and improving the patients' life expectancy.

Keywords: anemia, hemoglobin, prevalence, ageing, mortality

Marton I, Agócs Sz, Babik B. [Epidemiology of anemia]. Orv Hetil. 2020; 161(37): 1569-1573.

(Beérkezett: 2020. május 23.; elfogadva: 2020. június 20.)

\begin{abstract}
Rövidítések
ELEF = Európai lakossági egészségfelmérés; EPO = eritropoetin; $\mathrm{EU}=$ Európai Unió; $\mathrm{Hb}=$ hemoglobin; $\mathrm{MCH}=($ mean cell hemoglobin) átlagos vörösvérsejt-hemoglobin; $\mathrm{MCV}=$ (mean corpuscular volume) átlagos vörösvérsejt-térfogat; $\mathrm{WHO}=($ World Health Organization) Egészségügyi Világszervezet
\end{abstract}

Az anaemia gyakori előfordulása világszerte problémát jelent, egy 2013-ban készült, Globális betegségteher címü felmérés szerint a népesség 27\%-át, 1,93 milliárd embert érint [1]. Bár az anaemia háttere összetett és multifaktoriális, az esetek kétharmadában a vashiány a leggyakoribb ok. Az etiológia szerinti megoszlás (csökkent bevitel, felszívódás, krónikus vérvesztés, infekció 
stb.) nagy változatosságot mutat az életkortól, nemtől, földrajzi elhelyezkedéstől függően. A Globális betegségteher c. tanulmány (Global Burden of Disease Study 1990-2016) összefoglalója az ötödik leggyakoribb eltérésnek rangsorolta a vashiányos anaemiát [2]. A vér oxigénszállító kapacitásának, a hemoglobin koncentrációjának csökkenése esetén beszélünk vérszegénységről (anaemia). Az Egészségügyi Világszervezet (WHO) kritériumai szerint az anaemia férfiak esetén a $\mathrm{Hb}<130 \mathrm{~g} / \mathrm{l}$, nők esetén pedig a $\mathrm{Hb}<120 \mathrm{~g} / 1$ értéket jelenti [3]. Az anaemia jellemzésében és elkülönítő diagnosztikájában a hemoglobinértéken kívül számos, könnyen hozzáférhető laboratóriumi paraméternek van szerepe, úgymint: MCV (átlagos vörösvérsejt-térfogat), MCH (átlagos vörösvérsejt-hemoglobin), reticulocyta- és vörösvérsejtszám. A korábban széleskörúen használt, MCV-alapú felosztás helyett jelenleg a pontosabb, MCH-alapú diagnosztikus és kivizsgálási algoritmus tekinthető korszerűnek $[4,5]$.

$\mathrm{Az}$ átlagéletkor folyamatos növekedése nem feltétlenül jár együtt az egészségben eltöltött minőségi életévek számának növekedésével. A demográfiai változások, mint a javuló életkilátások és a fertilitási ráta csökkenése, öszszességében a népesség idősödéséhez vezet, amelynek üteme az egész világon drámai módon növekszik. 2015 és 2050 között a világ 60 évnél idősebb népességének aránya közel megduplázódik, 12\%-ról 22\%-ra (a jelenlegi 900 millióról várhatóan 2 milliárdra) [6]. A népesség elöregedése a gazdaságilag fejlett országokban kezdődött (például Japán), de jelenleg az alacsony és közepes jövedelmú országok néznek a legnagyobb léptékű változások elé. Míg Franciaországnak majdnem 150 éve volt arra, hogy alkalmazkodjon a 60 évesnél idősebb népesség arányának megkétszereződéséhez, addig Brazília, Kína és India esetében az elkövetkezendő 20 év alatt kell a megváltozott demográfiai helyzet kihívásainak megfelelni. Az EU 28 tagállamában 2014-ben a lakosság 18,5\%-a tartozott az idős korosztályba (a legmagasabb arányban Olaszországban: $21,4 \%$, a legalacsonyabb arányban Írországban: 12,6\%) [7].

Magyarországon is jelentősen nőtt a születéskor várható élettartam: míg egy 1949-ben született férfi 59,3, egy ugyanekkor született nő pedig 63,4 évre számíthatott, addig 2014-ben már 72,1, illetve 79,4 évre, de így is jelentősen elmaradunk az EU átlagától, amely férfiaknál 78,1, nőknél 83,6 év [8,9]. Az utóbbi évtizedekben hazánkban is nőtt a 65 évesek és az annál idősebbek aránya: 1949-ben 7,5\% volt a teljes népességen belül, 2014 ben pedig $17,5 \%$. Az egészségi korlátoktól mentes, egészséges élettartamot vizsgálva, 2014-ben az EU-ban egy férfi átlagosan 61,4, egy nő 61,8 egészséges életévre számíthatott, ami a férfiak teljes élettartamának 79\%-át, a nőkének 74\%-át jelenti. Magyarországon a 2014-ben született férfiak átlagosan 58,9, míg a nők 60,8 egészséges életévre számíthatnak; a 65 évesek a hátralévő életükből 6 évet tudnak még egészségben eltölteni (az EU-ban 8,6 évet) [9]. A népesség idősödése így azzal a következménnyel is jár, hogy az egészségi korlátozottsággal járó életévek száma emelkedik, főként a krónikus betegségek, kórállapotok prevalenciájának növekedése miatt.

Egészség-gazdaságtani elemzésekből jól ismert tény, hogy az egészségügyi ellátórendszer igénybevétele 65 éves kor felett exponenciálisan növekszik, és az egészségügyi kiadások döntő részét a társadalmak jelenleg is az idős korosztály ellátására fordítják [10].

Az Európai lakossági egészségfelmérés 2014 (ELEF 2014) keretein belül készült hazai adatfelvétel során azt találták, hogy Magyarországon a 65 éves és annál idősebb férfiak és nők közül egyaránt tízből heten vettek igénybe járó- vagy fekvőbeteg-ellátást a megkérdezésüket megelőző négy héten belül [9]. Amennyiben a 65 év felettiek az élettartam növekedésével nyert életévekben egészségesek maradnak, az egészségügyi ellátórendszer kiadásai évente átlagosan mindössze $0,48 \%$-kal emelkednek, ha viszont csak egy részét töltik az egyének jó egészségi állapotban, az évenkénti egészségügyi kiadás növekedése 1,87\%-ra becsülhető [10].

\section{Anaemiaprevalencia}

Az időskori anaemia prevalenciájával kapcsolatos ismeretek Európában és Észak-Amerikában végzett epidemiológiai tanulmányokból származnak, amelyek a WHO általánosan elfogadott, 50 évvel korábbi anaemiadefinícióján alapulnak $[3,11-13]$. A klasszikus definíciót számos bírálat érte, és a késóbbi, nagy adatbázisokon alapuló, az életkort, etnikumot is figyelembe vevő alternatív definíció pontosította a fenti értékeket (a 60 év feletti fehér [kaukázusi] férfiak esetén $132 \mathrm{~g} / 1$, míg a nőknél $122 \mathrm{~g} / \mathrm{l}$; fekete [afroamerikai] férfiak esetén $127 \mathrm{~g} / 1$, nőknél 117 g/l) [14]. Több tudományos geriátriai társaság azonban nemtôl függetlenül azonos hemoglobinküszöbértéket, $\mathrm{Hb}<120 \mathrm{~g} / \mathrm{l}-\mathrm{t}$ javasol definícióként [15].

Az anaemia prevalenciája emelkedik az életkorral [12] (1. ábra). Az anaemia WHO-kritériumait használó, 85409 idős adatait feldolgozó, 34 tanulmányt összegző szisztematikus összefoglaló megállapította, hogy időskorban a leggyakrabban diagnosztizált eltérés az anaemia, globális prevalenciája 17\%, amely az EU-ra vetítve 15 millió idős embert érint $[16,17]$. Az anaemiaprevalencia a lakóközösségekben élő 65 év felettiek csoportjá-

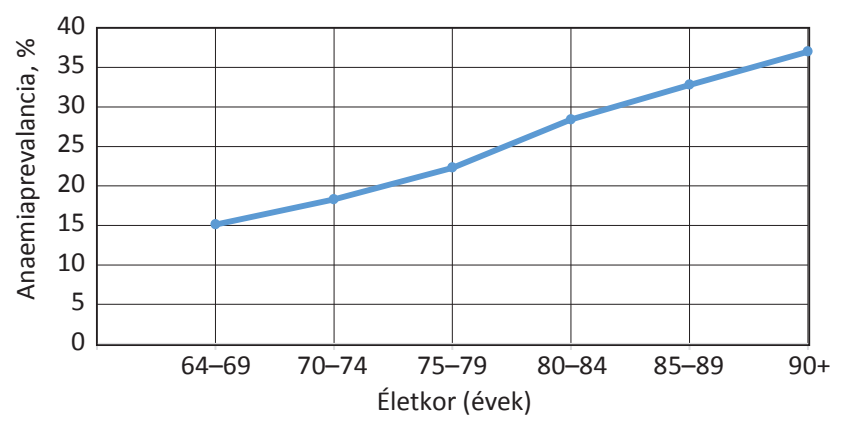

1. ábra Anaemiaprevalencia az életkor függvényében (V. Bach et al. ada tai alapján [12]) 
ban 12\% (3-25\%), az ápolási otthonokban élők csoportjában $47 \%(31-50 \%)$ és a hospitalizációra került idősek között 40\% (40-70\%) [16]. A közösségben élő 80 év felettiek korcsoportjában az anaemiaprevalencia meghaladja a $25 \%$-ot [16].

$\mathrm{Az}$ anaemia mindig következményes eltérés, a hátterében meghúzódó ok, alapbetegség sokféle lehet, mint például hiányanaemia, vérzés, krónikus gyulladás, tumor, krónikus vesebetegség, klonális hematológiai betegség.

1. táblázat Időskori, anaemiával társuló betegségcsoportok (R. Stauder et al. adatai alapján [18])

\begin{tabular}{ll}
\hline Betegségcsoportok & Példák \\
\hline $\begin{array}{l}\text { Krónikus gyulladásos betegségek } \\
\text { Autoimmun betegségek }\end{array}$ & $\begin{array}{l}\text { Rheumatoid arthritis, polymyal- } \\
\text { gia rheumatica } \\
\text { Krónikus hepatitis, osteomyelitis } \\
\text { Krónikus lábszárfekély, cachexia }\end{array}$ \\
$\begin{array}{ll}\text { Egyéb } & \\
\text { Daganatos betegségek } & \text { Colorectalis daganatok, } \\
\text { Gem hematológiai) } & \text { gyomordaganat } \\
\text { Tógstródiumú carcinomák betinalis tumorok } & \text { Számos daganattípus esetén, } \\
\text { Csontvelöi metastasis } & \text { például prosztata, emlö }\end{array}$ \\
\hline
\end{tabular}

Endokrin és metabolikus okok

Alacsony EPO-termelés

Pajzsmirigy-diszfunkció

Inzulindeficientia

Renalis anaemia vagy alacsony EPO-válasz

Hypo-, hyperthyreoidismus Diabetes mellitus

\section{Vérvesztés}

Gastrointestinalis traktusból

okkult vérzés

Diffúz gastrointestinalis vérzés

Sebészeti beavatkozás

Egyéb lokalizációkból vérzés

Gastricus ulcus, erózió, colitis ulcerosa

Antikoaguláns kezeléssel

kapcsolatos vérzés

Többszörös hasi mútét

Epistaxis, haematuria

Fokozott vörösvérsejt-pusztulás

vagy sequestratio

Immunhaemolysis

Vörösvérsejtek mechanikus

károsodása

Hypersplenismus

Autoimmun haemolysis

Mechanikus szívbillentyű okozta

haemolysis

Hepatosplenomegalia

\section{Hiányállapotok}

Vitamin

Nyomelemek hiánya

Vashiány

$\mathrm{B}_{12^{-}}$, folsavhiány

Rézhiány

Vérveszteség

Gyógyszer indukálta anaemia

Kemoterápiás szerek

Kemoterápia indukálta pancytopenia

Antimetabolitok, antiepileptiku- Szerzett folsavhiány

mok

Toxikus/immun mechanizmusú reakció

\begin{tabular}{ll}
\hline Infektív okok & $\begin{array}{l}\text { Bélférgesség, malária, tbc, HIV, } \\
\text { egyéb }\end{array}$ \\
\hline Haemoglobinopathiák & $\begin{array}{l}\text { Béta-thalassaemia, sarlósejtes } \\
\text { anaemia }\end{array}$ \\
\hline
\end{tabular}

$\mathrm{EPO}=$ eritropoetin; HIV = emberi immunhiányt előidéző vírus; tbc = tuberkulózis
Idős betegeknél általában enyhe anaemiáról van szó (a Hb-érték az alsó normálhatárérték alatt, de $\mathrm{Hb}>100$ $\mathrm{g} / \mathrm{l}$ ), és előfordulhat, hogy több, különböző kiváltó tényező egyidejü fennállása vezet az anaemia kialakulásához [18] (1. táblázat). A komorbiditások száma is nő az életkorral: a 80 év felettiek közel $40 \%$-a már több mint 4 társbetegséggel rendelkezik, köztük gyakran olyan állapotokkal, amelyek maguk is anaemiával járnak, mint például krónikus vesebetegség, szívelégtelenség [18, 19]. $\mathrm{Az}$ esetek egy részében ún. „megmagyarázatlan, avagy nem megfelelően vizsgált?” anaemia áll fenn, melynek etiológiájaként több tényezőt is feltételeznek (androgéndeficientia; D-vitamin-hiány; megváltozott eritropoetin [EPO]-homeostasis; klonális haematopoesis; illetve az öregedéssel összefüggő, a proinflammatorikus citokinek túlsúlyát okozó szubklinikus, krónikus gyulladásos állapot) [17]. Mindehhez a vérképzés életkorral összefüggő változásai is hozzájárulnak, úgymint a vese-EPO-válasz csökkenése időskorban a vesefunkció beszúküulése nélkül, valamint a csontvelői vérképző őssejtek kvalitatív eltérései az öregedés során (az őssejtek önmegújító és differenciálódóképességének csökkenése) [20].

\section{$\mathrm{Az}$ anaemia és a kedvezőtlen kimenetel összefüggései}

Az utóbbi évtizedekben egyre több a bizonyíték arra vonatkozóan , hogy az idősek anaemiája - még ha enyhe anaemiáról van is szó - közvetetten jelzi a gyengébb egészségi állapotot, a fokozott sérülékenységet és a kedvezőtlen kimenetelt [17]. Az anaemia a számos következménye miatt bír jelentőséggel, hiszen a kognitív funkciók csökkenése, rosszabb fizikai általános állapot és életminőség, esés, törések veszélye, valamint nagyobb cardiovascularis kockázat és mortalitási rizikó társul hozzá [21]. Amennyiben enyhe anaemia már a kórházi felvételkor jelen volt, egy tanulmány szerint a betegek felénél az anaemia tovább romlott, és iatrogén anaemiával is súlyosbodott, amely egyértelmúen emelkedett halálozási kockázattal jár. A kórházi halálozás kockázata, az ápolási napok hossza, költségek növekedése a iatrogén anaemia mértékével párhuzamosan emelkedett [22].

Egy 188 447, kórházi felvételre került belgyógyászati és sebészeti beteg adatait vizsgáló amerikai tanulmány azt találta, hogy a betegek 74\%-ánál alakult ki anaemia a kórházi bennfekvés alatt (iatrogén anaemia). Akiknél iatrogén anaemia alakult ki, idősebbek voltak, és több társbetegséggel rendelkeztek, mint azok, akik nem váltak anaemiássá. Az anaemia mértékétől függően mind a halálozás, mind az ápolási napok száma és a költségek növekedést mutattak [23].

Több, az idős népesség körében végzett tanulmány is egyértelmúvé tette az anaemia és az emelkedett halálozási kockázat összefüggését [24, 25]. A 66 év feletti, lakóközösségekben élő, 17030 idős körében végzett felmérés igazolta, hogy az anaemia fokozott rizikót jelent a bármilyen okból bekövetkező halálozás, kórházi felvétel 
és a cardiovascularis okból történő kórházi felvétel szempontjából, míg egy másik vizsgálatban a hospitalizációra került idősek körében a felvételkori vagy elbocsátáskori anaemia erôs előre jelző faktor a három hónapon belüli halálozás szempontjából [26, 27].

A mütétre felvett betegek körében kiterjedten vizsgálták a preoperatív anaemia előfordulását. Több mint 650000 beteget magában foglaló, 18 jelentős obszervációs vizsgálat adatai alapján az átlagos prevalencia $35 \%$, de szakterületenként nagy változatosságot mutat $(10,5-$ $47,9 \%$ ) a vizsgált betegpopulációtól, a mútéttípustól (ortopédia, érsebészet, hasi sebészet, nőgyógyászat) és a vizsgálatban meghatározott anaemiadefiníciótól függően [28]. A mútét előtti anaemia a kedvezőtlen kimenetelt jelzi előre, hiszen fennállása esetén a fertőzés kockázata közel kétszeres, az akut vesekárosodás veszélye négyszeres, a transzfúzió szükségességének valószínúsége ötszörös, a mortalitási rizikó pedig háromszoros [2931].

\section{Következtetés}

Az anaemia világszerte jelentős probléma, mivel magas a prevalenciája, és a demográfiai változások, a népesség idősödése miatt még további emelkedése várható. Az időskori anaemia különösképp figyelmet érdemel még enyhe formában is, mivel kedvezőtlen kimenetelt jelez, rövidebb túléléssel, magasabb halálozási kockázattal társul. Mivel patogenezise összetett, és a társbetegségek miatt gyakran multifaktoriális, diagnosztikája és kezelése is komplex feladat.

A mútét előtti anaemia prevalenciája magasabb, mint az anaemia gyakorisága az átlagpopulációban, kedvezőtlenül hat a posztoperatív morbiditásra és mortalitásra, ezért időben történő felismerése és korrekciója feltétlenül szükséges mind a vértakarékos betegellátás, mind a betegek életkilátásainak javítása szempontjából.

Anyagi támogatás: A közlemény megírása és a kutatómunka anyagi támogatásban nem részesült.

Szerzői munkamegosztás: A szerző́k egyenlő arányban vettek részt a dolgozat elkészítésében. A cikk végleges változatát valamennyi szerző elolvasta és jóváhagyta.

Érdekeltségek: A szerzőknek nincsenek érdekeltségeik.

\section{Irodalom}

[1] Kassebaum NJ, on behalf of GBD 2013 Anemia collaborators. The global burden of anemia. Hematol Oncol Clin N Am. 2016; 30: 247-308

[2] GBD 2016 Disease and Injury Incidence and Prevalence Collaborators. Global, regional, and national incidence, prevalence, and years lived with disability for 328 diseases and injuries for 195 countries, 1990-2016: a systematic analysis for the Global Burden of Disease Study 2016. Lancet 2017; 390: 1211-1259. [Correction: Lancet 2017; 390: e38.]
[3] Nutritional anaemias. Report of a WHO scientific group. World Health Organ Tech Rep Ser. 1968; 405: 5-37.

[4] Egyed M. A simple algorithm of anemia. [Az anaemia egyszerú algoritmusa.] Orv Hetil. 2014; 155: 376-382. [Hungarian]

[5] Kellner SV, Kellner Á, Haragh A, et al. Low mean cell hemoglobin is a reliable marker for iron deficiency screening. [Az alacsony átlagos vörösvértest-hemoglobin alkalmas a vashiány szưrésére.] Orv Hetil. 2016; 157: 35-38. [Hungarian]

[6] World Health Organization. Ageing and health. WHO, Geneva, 5 February 2018. Available from: https://www.who.int/newsroom/fact-sheets/detail/ageing-and-health [accessed: June 3, 2020].

[7] European Commission. Employment, social affairs \& inclusion - Eurostat Demography Report, 2015. Publications Office of the European Union, Luxembourg, 2015. Available from: http://ec.europa.eu/eurostat/documents/3217494/ 6917833/KE-BM-15-003-EN-N.pdf/76dac490-9176-47bc80d9-029eld967af6 [accessed: June 3, 2020].

[8] Hungarian Central Statistical Office. Statistical Yearbook of Hungary, 2014. [Magyar statisztikai évkönyv, 2014.] Központi Statisztikai Hivatal, Budapest, 2015. Available from: http:// www.ksh.hu/docs/hun/xftp/idoszaki/evkonyv/evkonyv_ 2014.pdf [accessed: June 3, 2020]. [Hungarian]

[9] Boros J. Health in old age. In: Giczi J. (ed.) Silver age: ageing and society. [Egészség időskorban. In: Giczi J. ( szerk.) Ezüstkor: korosodás és társadalom.] Központi Statisztikai Hivatal, Budapest, 2017; pp. 35-50. [Hungarian]

[10] Harris A, Sharma A. Estimating the future health and aged care expenditure in Australia with changes in morbidity. PLoS ONE 2018; 13: e0201697.

[11] Tettamanti M, Lucca U, Gandini F, et al. Prevalence, incidence and types of mild anemia in the elderly: the "Health and Anemia" population-based study. Haematologica 2010; 95: 18491856

[12] Bach V, Schruckmayer G, Sam I, et al. Prevalence and possible causes of anemia in the elderly: a cross-sectional analysis of a large European university hospital cohort. Clin Interv Aging 2014; 9: 1187-1196.

[13] Guralnik JM, Eisenstaedt RS, Ferrucci L, et al. Prevalence of anemia in persons 65 years and older in the United States: evidence for a high rate of unexplained anemia. Blood 2004; 104: 22632268.

[14] Beutler E, Waalen J. The definition of anemia: what is the lower limit of normal of the blood hemoglobin concentration? Blood 2006; 107: 1747-1750.

[15] Andrès E, Serraj K, Federici L, et al. Anemia in elderly patients: new insight into an old disorder. Geriatr Gerontol Int. 2013; 13: $519-527$

[16] Gaskell H, Derry S, Andrew Moore RA, et al. Prevalence of anaemia in older persons: systematic review. BMC Geriatr. 2008; 8: 1 .

[17] Girelli D, Marchi G, Camaschella C. Anemia in the elderly. Hemasphere 2018; 2: e40.

[18] Stauder R, Valent P, Theurl I. Anemia at older age: etiologies, clinical implications, and management. Blood 2018; 131: 505514.

[19] Barnett K, Mercer SW, Norbury M, et al. Epidemiology of multimorbidity and implications for health care, research, and medical education: a cross-sectional study. Lancet 2012; 380: 37-43.

[20] Merchant AA, Roy CN. Not so benign haematology: anaemia of the elderly. Br J Haematol. 2012; 156: 173-185.

[21] Stauder R, Thein SL. Anemia in the elderly: clinical implications and new therapeutic concepts. Haematologica 2014; 99: 11271130 .

[22] Koch CG, Li L, Sun Z, et al. From bad to worse: anemia on admission and hospital-acquired anemia. J Patient Saf. 2017; 13: 211-216 
[23] Koch CG, Li L, Sun Z, et al. Hospital-acquired anemia: prevalence, outcomes, and healthcare implications. J Hosp Med. 2013; 8: 506-512.

[24] Shavelle RM, MacKenzie R, Paculdo DR. Anemia and mortality in older persons: does the type of anemia affect survival? Int J Hematol. 2012; 95: 248-256.

[25] Martinsson A, Andersson C, Andell P, et al. Anemia in the general population: prevalence, clinical correlates and prognostic impact. Eur J Epidemiol. 2014; 29: 489-498.

[26] Culleton BF, Manns BJ, Zhang J, et al. Impact of anemia on hospitalization and mortality in older adults. Blood 2006; 107: 3841-3846.

[27] Riva E, Colombo R, Moreo G, et al. Prognostic value of degree and types of anaemia on clinical outcomes for hospitalised older patients. Arch Gerontol Geriatr. 2017; 69: 21-30.

[28] Muñoz M, Gómez-Ramírez S, Campos A, et al. Pre-operative anaemia: prevalence, consequences and approaches to management. Blood Transfus. 2015; 13: 370-379.
[29] Beattie WS, Karkouti K, Wijeysundera DN, et al. Risk associated with preoperative anemia in noncardiac surgery: a single-center cohort study. Anesthesiology 2009; 110: 574-581.

[30] Fowler AJ, Ahmad T, Phull MK, et al. Meta-analysis of the association between preoperative anaemia and mortality after surgery. Br J Surg. 2015; 102: 1314-1324

[31] Musallam KM, Tamim HM, Richards T, et al. Preoperative anaemia and postoperative outcomes in non-cardiac surgery: a retrospective cohort study. Lancet 2011; 378: 1396-1407.

(Marton Imelda dr., Szeged, Semmelweis u. 8., 6725 e-mail: imeldamarton@gmail.com)

\section{MEGHÍ Vó}

\section{Az Észak-Közép-budai Centrum, Új Szent János Kórház és Szakrendelő Tudományos Bizottsága tisztelettel meghívja az érdeklődőket a következő tudományos ülésére.}

Időpont: 2020. szeptember 24-én (csütörtök) 14 óra Helyszín: Szent János Kórház Auditóriuma - 1125 Budapest, Diós árok 1-3. Téma: A máj sebészete: Milyen mütéti lehetőségei vannak a sebésznek?

Üléselnök: Prof. Dr. Jánosi András

\section{Program:}

Lukovich Péter dr.: A máj sebészetének története 10 perc Pőcze Balázs dr.: A máj ereit infiltráló tumor mütétje 10 perc Szpiszár Tamás dr.: Tumor és áttétje miatt egy ülésben végzett vastagbél- és májresectio 10 perc Nagy Jenö dr.: A laparoscopos májresectio Ram Rokka dr.: „Liver first approach” Lukovich Péter dr., Pőcze Balázs dr.: Ritka mütéti megoldások (transzplantáció, ex situ májmütét, ALPPS)

Minden érdeklődőt szeretettel várunk! illetve a CC License linkje és az esetlegesen végrehajtott módosítások feltüntetésre kerülnek. (SID_1) 